\title{
Lesion regeneration in the branching coral Acropora palmata: effects of colonization, colony size, lesion size, and lesion shape
}

\author{
Diego Lirman* \\ Center for Marine and Environmental Analyses, Rosenstiel School of Marine and Atmospheric Science, \\ University of Miami, 4600 Rickenbacker Cswy, Miami, Florida 33149, USA
}

\begin{abstract}
The regeneration of lesions caused by the fragmentation of Acropora palmata colonies was examined in the northern Florida Reef Tract, USA. The recovery of $A$. palmata lesions followed a negative exponential model. Lesion regeneration was influenced by the initial size and perimeter of lesions, but was not affected by the presence of colonizers or the size of the colonies or fragments bearing the lesions. Significant differences in regeneration rates were found among small $\left(0-5 \mathrm{~cm}^{2}\right)$, medium $\left(5-10 \mathrm{~cm}^{2}\right)$, and large $\left(10-20 \mathrm{~cm}^{2}\right)$ lesions. The largest lesions $\left(>20 \mathrm{~cm}^{2}\right)$ did not show a significant recovery over time. When the total area recovered during the first $30 \mathrm{~d}$ was normalized to initial perimeter length, both small and large lesions regenerated similar amounts of tissue. However, closure rates (the rate of movement of the growing lip towards the center of the lesion) were significantly faster for small lesions $\left(7.3[\mathrm{SE}=1.3] \mathrm{mm} \mathrm{mo}^{-1}\right)$ compared to medium $\left(4.9[0.4] \mathrm{mm} \mathrm{mo}^{-1}\right)$ and large $(4.3$ [0.3] $\mathrm{mm} \mathrm{mo}^{-1}$ ) lesions. Results of this study support previous studies suggesting that the regeneration process is sustained by a limited, initial amount of energy that may be determined by the extent of damage experienced by the colony.
\end{abstract}

KEY WORDS: Coral lesions - Lesion regeneration - Acropora palmata C Coral fragmentation - Lesion size and shape

\section{INTRODUCTION}

Coral colonies experience frequent, small-scale disturbances that result in the partial loss of tissue. Injuries or lesions on corals can be created by physical and biological agents such as storms, sedimentation, diseases, high temperature, predation, competition for primary space, human activities, and pollution (Connell 1973, Glynn 1973, Loya 1976, Bak \& Van Es 1980, Bak \& Criens 1981, Knowlton et al. 1981, 1988, Rogers et al. 1982, Bak 1983, Hutchings 1986, Hawkins \& Roberts 1992, Bythell \& Sheppard 1993, Guzmán et al. 1994). The regeneration of lesions can represent a significant drain on the energetic resources available for coral maintenance, growth and reproduction, and can

\footnotetext{
-E-mail: dlirman@rsmas.miami.edu
}

have long-lasting effects on the composition and survivorship of reef communities (Loya 1976, Gladfelter et al. 1977, Bak 1983, Wahle 1983, Kobayashi 1984, Liddle \& Kay 1987, Meesters et al. 1992, 1994, 1996, Guzmán et al. 1994, Van Veghel \& Bak 1994, Lirman 1997).

Previous research on the regeneration of experimentally inflicted coral lesions has shown that several factors can influence the recovery process, including lesion size and shape, overall extent of damage, position of lesions within a colony, and size of the colonies bearing the lesions (Loya 1976, Bak et al. 1977, Bak \& Van Es 1980, Bak 1983, Chadwick \& Loya 1990 , Meesters et al. 1992, 1994, 1997, Oren et al. 1997, van Woesik 1998). The fragmentation of Acropora palmata colonies by storms and boat impacts provided an excellent opportunity to test the effects of these and some additional factors on the regeneration of lesions created by the detachment of coral branches. 
Acropora palmata (elkhorn coral) is a dominant species in the shallow, exposed areas of reefs throughout the Caribbean (Wells 1988). The dominance of this coral species in high-energy zones has been attributed to its plastic morphology, strong skeleton, rapid growth, and ability to form new colonies from fragments (Graus et al. 1977, Chamberlain 1978, Gladfelter et al. 1978, Schuhmacher \& Plewka 1981, Highsmith 1982, Gladfelter 1991, Lirman \& Fong 1997). A. palmata has also good regenerative capabilities, as evidenced by the rapid recovery of small, circular experimental lesions (Bak 1983, Meesters \& Bak 1995). Colonies of A. palmata on the Florida Reef Tract undergo periodic fragmentation (Lirman 1997), and the resulting lesions can be colonized by algae and other organisms (Rogers et al. 1982, Bak 1983). Since linear extension of broken $A$. palmata branches can be delayed or slowed down until the resulting lesions are completely recovered, and the colonization of lesions by bioeroders can weaken colonies (Hernandez-Ávila et al. 1977, Mitchell-Tapping 1983), it is of great importance for A. palmata colonies to recover these lesions rapidly.

Although large scale, acute events such as hurricanes, disease or predator outbreaks, and bleaching concentrate scientific attention due to their often catastrophic effects; smaller scale, chronic disturbances may also have considerable impacts on coral populations. The regeneration of lesions caused by the periodic fragmentation of Acropora palmata by storms or boat impacts may represent a significant energetic drain for damaged colonies and, considering that lesion regeneration can affect other vital processes such as growth and sexual reproduction, it may play a significant role in the long-term survivorship of $A$. palmata populations in the Florida Reef Tract. The objectives of this study were to test if regeneration of $A$. palmata lesions caused by fragmentation is affected by: (1) the size of the colonies or fragments bearing the lesions; (2) the size and shape of lesions; and (3) the colonization of lesions by algae and other organisms.

\section{METHODS}

The recovery of lesions on Acropora palmata colonies and fragments was examined at Elkhorn Reef $\left(25^{\circ} 21.766^{\prime} \mathrm{N}, 80^{\circ} 09.961^{\prime} \mathrm{W}\right)$ in the northern Florida Reef Tract, USA. This reef has a well-developed $A$. palmata coral population that undergoes periodic fragmentation (Lirman \& Fong 1995, 1996). The lesions monitored in this study were all produced by the detachment of A. palmata branches from adult colonies as a result of storms or boat impacts.

Elkhom Reef was surveyed at weekly intervals during the summers of 1994 and 1995. Whenever boat or storm damage was detected (as evidenced by the appearance of coral lesions showing a bright, white skeleton devoid of significant algal colonization), lesions were labeled and subsequently photographed at different time intervals with a Nikonos $V$ camera equipped with a $28 \mathrm{~mm}$ lens and close-up lens outfit. Outlines for all lesions were scanned and surface area and perimeter for each lesion were estimated with NIH Image Software.

The recovery process was evaluated by calculating: (1) regeneration rates (change in lesion size with time; $\mathrm{cm}^{2} \mathrm{~d}^{-1}$ ), (2) linear closure rates (rate of movement of the growing lip towards the center of the lesion $\mathrm{mm}^{\mathrm{m}}$ $\mathrm{mo}^{-1}$ ), and (3) total amount of tissue regenerated during the first $30 \mathrm{~d}\left(\mathrm{~cm}^{2}\right)$. To determine closure rates, 12 radial measurements were taken for each lesion from the edge of the growing lip towards the center of the lesion along 6 axes drawn on acetate paper and placed over the photographs. Measurement were taken at each time interval and averaged for small, medium, and large lesions.

Effects of colonizers. Thirty lesions created by a boat grounding in June 1994 were tagged and assigned to 1 of 2 groups at random. Lesions in the experimental group were brushed free of any filamentous algae at bi-weekly intervals using a plastic denture brush. The algal removal was done with extreme care to avoid damaging the coral polyps developing along the growing edge of the lesions. To minimize any differences between groups resulting from the stress caused by brushing, the brush was passed very lightly over the control lesions without removing any of the colonizing algae.

Effects of lesion size and shape. Seventy Acropora palmata lesions caused by Tropical Storm Gordon were marked in November 1994, less than a week after the storm, and their recovery followed through time. Lesions were grouped into 4 size categories: small $\left(0-5 \mathrm{~cm}^{2}\right)$, medium $\left(5-10 \mathrm{~cm}^{2}\right)$, large $\left(10-20 \mathrm{~cm}^{2}\right)$, and extra-large $\left(>20 \mathrm{~cm}^{2}\right)$.

Recovery of lesions on colonies and fragments. In August 1995, a boat impacted the Acropora palmata population on Elkhorn Reef and many of the fragments produced could be found resting on top of their colony of origin or on the bottom nearby. Newly created fragments were chosen so that their lesions matched those on their colonies of origin, and lesions were tagged on both colonies and fragments. The fragments were tied with monofilament line to large pieces of coral rubble and placed on the bottom near the standing colonies. Maximum linear diameter of colonies bearing the lesions and surface area of the fragments were estimated to evaluate the effects of colony and fragment size on the regeneration of lesions. 
Statistical methods. Size of lesions was regressed against time since injury. To normalize the data, lesion size was logarithmically transformed $(\ln (x+1)$; Sokal \& Rohlf 1981). Data for each lesion were fitted to the exponential model: lesion size $=a \cdot \mathrm{e}^{(-b \cdot \text { days })}$ using a least squares procedure. Regression parameters (slope and intercept) were averaged within groups (Meesters et al. 1997). Differences among regeneration rates were tested among all groups with ANCOVA (Sokal \& Rohlf 1981). The relationships between lesion size, perimeter, shape (perimeter/area ratio), colony and fragment size, and the amount of tissue regenerated during the first $30 \mathrm{~d}$ were tested with regression.

\section{RESULTS}

A thick, growing lip developed within $2 \mathrm{wk}$ around the edges of the lesions (Fig. 1). New polyps could be observed behind this growing lip as it moved towards the center of the lesion. Regeneration rates of lesions on Acropora palmata decreased exponentially with time as shown by a good fit to the exponential model (Table 1). An exception to this pattern are the extralarge lesions $\left(<20 \mathrm{~cm}^{2}\right)$ that did not show a significant recovery over the time of the study. Regeneration rates were strongly size-dependent (Table 1, Fig. 2), and significant differences in regeneration rates were found among all 3 groups tested (i.e., small, medium, and large; ANCOVA, p < 0.05). Given the lack of regeneration, extra-large lesions were excluded from the analysis.

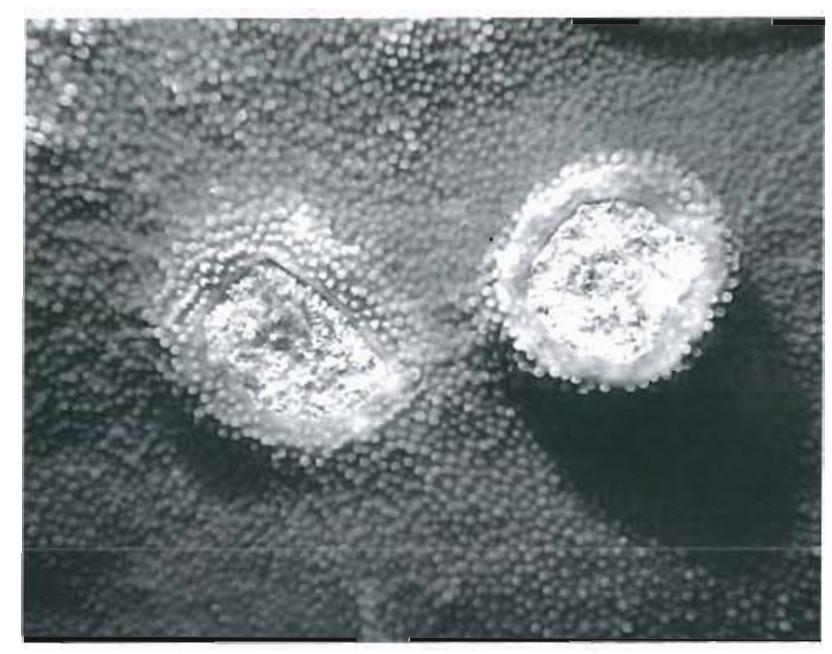

Fig. 1. Acropora palmata. Close-up photograph of a lesion caused by the detachment of a branch during Tropical Storm Gordon (November 1994) showing the formation of the growing lip that moves towards the center of the lesion as regeneration proceeds
Linear closure rates decreased exponentially with time for all lesion sizes (Fig. 3) and were influenced by initial lesion size. Mean closure rates for the first $30 \mathrm{~d}$ were significantly faster for small lesions (7.3 [SE = 1.3] mu $\mathrm{mo}^{-1}$ ) compared to medium (4.9 [0.4] $\mathrm{mm} \mathrm{mo}^{-\mathrm{t}}$ ) and large $\left(4.3[0.3] \mathrm{mm} \mathrm{mo}^{-1}\right)$ lesions (ANCOVA, $\mathrm{p}<0.05$, Tukey a posteriori comparisons test). No significant differences in closure rates were found between medium and large lesions.

For the lesions created by Tropical Storm Gordon on Elkhorn Reef, lesion perimeter and initial area were positively correlated ( $r=0.90)$. In contrast, the complexity of lesion shape, as estimated by the perimeter/ area-ratio, was negatively correlated with lesion size $(r=-0.91)$. The total amount of tissue regenerated during the first $30 \mathrm{~d}$ was significantly affected by lesion size (Fig. 4A, $r^{2}=0.59, p<0.01$ ) and perimeter (Fig. 4B, $\left.\mathrm{r}^{2}=0.50, \mathrm{p}<0.01\right)$. When the area recovered during this period was normalized to initial perimeter length, although large lesions appeared to recover a larger amount of tissue, no significant relationships were established (Fig. 4C, $\mathrm{r}^{2}=0.08, \mathrm{p}>0.1$ ).

Control lesions that were heavily colonized by algae shortly after fragmentation recovered faster than brushed lesions devoid of colonizers (Table 1 , ANCOVA, $p<0.05$ ). At the end of this experiment (138 d), control colonies had recovered a larger percentage of their initial lesion area (94\%) compared to brushed lesions ( $81 \%)$.

Although standing colonies regenerated lesions of equal size slightly faster than fragments placed on the bottom, this difference was not statistically significant (Table 1, ANCOVA, p > 0.1). After 3 mo, colonies recovered a larger percentage of their original lesion area $(89 \%)$ compared to fragments $(70 \%)$. No significant relationships were found between either colony or fragment size and the total amount of tissue regenerated during the first $30 \mathrm{~d}$ (regression, $\mathrm{p}>0.1$ ).

Table 1. Regression parameters for the regression between lesion size and regeneration time. Regression parameters for each group represent means $( \pm 1 \mathrm{SE})$ of individual lesions fitted to the model: lesion size $=a \cdot e^{(-b \cdot d a y s)} \cdot n s=$ not significant, $\mathrm{p}_{\mathrm{reg}}=$ probabiltity of regression

\begin{tabular}{|lccccc|}
\hline Lesions & $\mathrm{N}$ & Intercept & Reg. coeff. & $\mathrm{r}^{2}$ & $\mathrm{p}_{\mathrm{reg}}$ \\
\hline Small & 20 & $3.1(0.4)$ & $-0.040(0.007)$ & 0.86 & $<0.01$ \\
Medium & 20 & $7.1(0.5)$ & $-0.021(0.002)$ & 0.77 & $<0.01$ \\
Large & 12 & $16.2(0.7)$ & $-0.012(0.002)$ & 0.73 & $<0.01$ \\
Extra-large & 12 & 31.3 & $\mathrm{~ns}$ & $n \mathrm{~ns}$ & $\mathrm{~ns}$ \\
& & & & & \\
Controls & 15 & $6.2(1.3)$ & $-0.032(0.002)$ & 0.73 & $<0.01$ \\
Brushed & 15 & $6.7(1.1)$ & $-0.024(0.003)$ & 0.66 & $<0.05$ \\
Colonies & 15 & $7.8(1.3)$ & $-0.018(0.004)$ & 0.73 & $<0.01$ \\
Fragments & 15 & $7.3(1.3)$ & $-0.013(0.004)$ & 0.50 & $<0.05$ \\
\hline
\end{tabular}



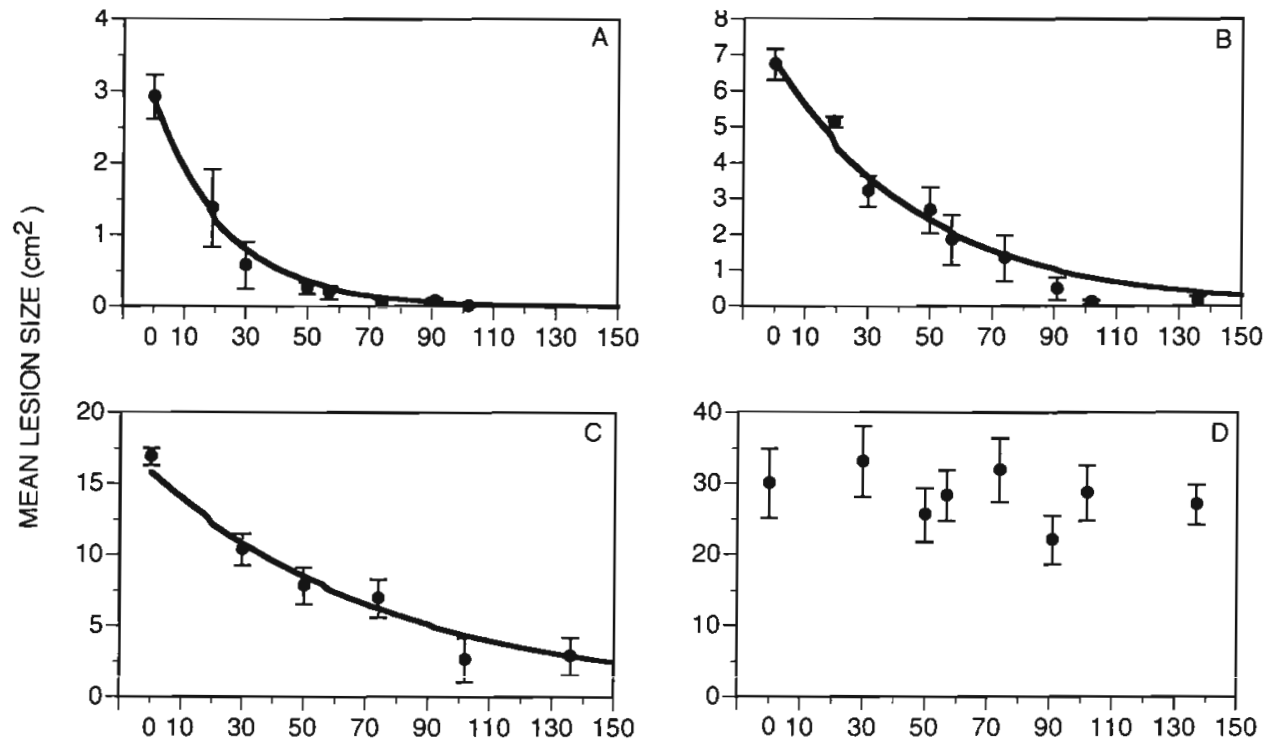

TIME (days)

Fig. 2. Acropora palmata. Change in mean size $( \pm 1 \mathrm{SEM})$ with time for $(\mathrm{A})$ small $\left(<5 \mathrm{~cm}^{2}, \mathrm{n}=20\right),(\mathrm{B}) \mathrm{medium}\left(5-10 \mathrm{~cm}{ }^{2}, \mathrm{n}=20\right)$, (C) large $\left(10-20 \mathrm{~cm}^{2}, \mathrm{n}=12\right)$, and (D) extra-large $\left(>20 \mathrm{~cm}^{2}, \mathrm{n}=12\right)$ lesions. Regression lines are averaged for individual lesions within groups fitted to the model: lesion size $=a \cdot e^{(-b \cdot d a y s)}$. Regression coefficients can be found in Table 1

\section{DISCUSSION}

Lesion regeneration on corals has been studied extensively using mainly small $\left(<5 \mathrm{~cm}^{2}\right)$, experimentallycreated lesions. In this study, it is shown that several previous findings can also be applied to the regeneration of a wide range of lesion sizes caused by fragmen-

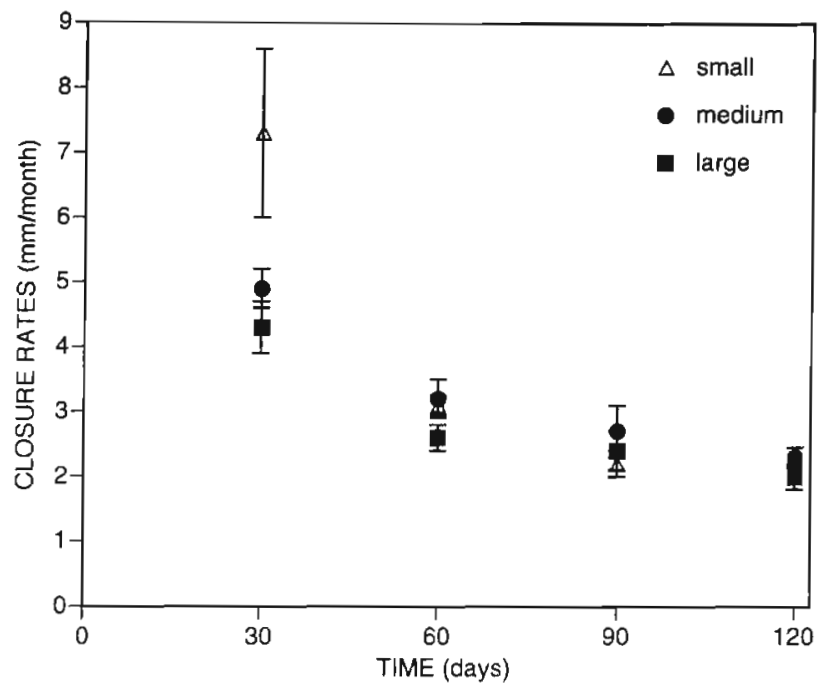

Fig. 3. Acropora palmata. Mean closure rates (movement of the growing lip towards center of lesion, $\pm 1 \mathrm{SEM}$ ). Small $=$ $<5 \mathrm{~cm}^{2}$, medium $=5-10 \mathrm{~cm}^{2}$, large $=10-20 \mathrm{~cm}^{2}$. Given the lack of recovery observed for lesions $>20 \mathrm{~cm}^{2}$, these were excluded from the analyses tation of Acropora palmata colonies. For A. palmata lesions created by storms or boat groundings, regeneration rates were dependent on initial lesion size and decreased exponentially with time. Whereas more than half of small lesions $\left(<5 \mathrm{~cm}^{2}\right)$ recovered completely during the first $30 \mathrm{~d}$, the largest lesions $\left(>20 \mathrm{~cm}^{2}\right)$ did not show any significant recovery over time. Similar effects of initial lesion size on recovery rates has been documented for experimental lesions (e.g., Bak \& van Es 1980, Oren et al. 1997, van Woesik 1998).

The exponential decrease in both lesion size and the movement rate of the growing lip with time observed here support the hypothesis that the regeneration of coral lesions is fueled by an initial, limited supply of energy drawn from the undamaged tissue on the colony bearing the lesion as proposed by Bak (1983) and Meesters et al. (1992, 1994, 1997). The faster initial closure rates of small lesions indicate that the regeneration process and the amount of resources available for regeneration may be related to the extent of the damage experienced by the fragmented colonies. In Acropora palmata, the size of a lesion is determined by the cross section of the broken branch. The detachment of a large branch results in a significant biomass loss and a potential drain of resources, resulting in the slower closure rates recorded for larger lesions.

The recovery of Acropora palmata lesions was influenced by lesion size and shape. The total amount of tissue recovered during the first month of regeneration was proportional to lesion size and perimeter. How- 
ever, when the amount of tissue recovered was normalized to initial perimeter length, small and large lesions recovered similar amounts of tissue. Similar results were obtained by Meesters et al. (1997) who concluded that perimeter length is the most important variable affecting lesion regeneration. In contrast, Oren et al. (1997) found that lesions with longer perimeters recovered relatively more tissue than lesions with shorter perimeters. Although these reports highlight the influence of perimeter length and lesion shape, the faster closure rates documented here for
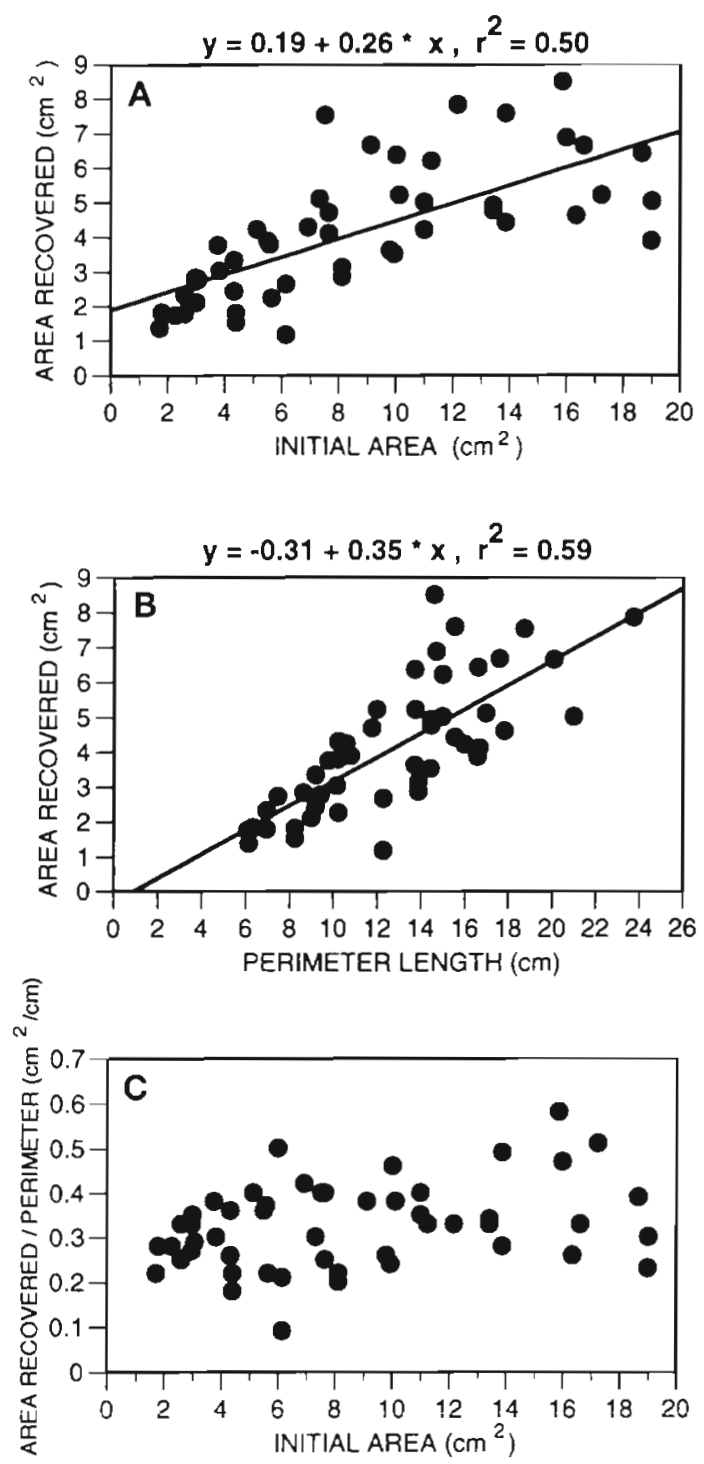

Fig. 4. Acropora palmata. Relationships between area recovered during the first month and (A) initial lesion size, (B) initial perimeter length, and (C) between area recovered per perimeter length and initial lesion size. Given the lack of recovery observed for lesions $>20 \mathrm{~cm}^{2}$, these were excluded from the analyses lesions with small initial areas and short perimeters suggest that size effects cannot be dismissed. Further studies such as those by Oren et al. (1997) that manipulate both size and shape are needed to fully understand the role of lesion size and perimeter on regeneration.

Another factor that may influence the recovery of lesions is their location within the damaged colonies. Meesters \& Bak (1995) documented a regenerationpotential gradient along Acropora palmata branches that decreases as distance from the branch tips increases. This regeneration gradient was attributed to the younger age of polyps at the branch tips, and the general mobilization of energy from basal portions towards the ends of branches where linear extension takes place (Pearse \& Muscatine 1971). The role of lesion position on regeneration of lesions created by fragmentation was not tested in this study but merits further investigation.

Previous studies suggest that Acropora palmata fragments and colonies may have different resource allocation strategies after fragmentation. Since lesions on colonies have to heal completely before linear extension of the damaged branches can resume (Lirman 1997), the rapid regeneration of lesions on colonies is crucial for the continued growth of damaged colonies. In contrast, newly-formed fragments direct most of their energy initially towards cementation to the bottom, and new growth was found to be delayed until this process is complete (Lirman \& Fong 1997). Based on this, it was hypothesized that lesions on colonies would recover faster than on fragments. Results presented here did not support the differential resource allocation hypothesis; although colonies regenerated a larger percentage of their initial lesion area compared to fragments, no significant differences in recovery rates were detected, suggesting that lesion recovery may be an important process for both $A$. palmata colonies and fragments.

The effects of colony size on lesion regeneration have been studied previously with differing results. Connell (1973) and Loya (1976) showed reduced regeneration capabilities in small coral colonies (8 to $80 \mathrm{~cm}^{2}$ ), whereas Bak \& Van Es (1980) and Wahle (1983) did not find any relationship between colony size and regeneration rates. Moreover, Chadwick \& Loya (1990) found that small solitary corals can recover faster than larger corals with similar amounts of damage. In this study, no significant relationship was found between regeneration of lesions and fragment or colony size, indicating that even small colonies $(50 \mathrm{~cm}$ in diameter) and fragments $\left(50 \mathrm{~cm}^{2}\right)$ are capable of regenerating lesions at rates similar to those of larger units. This supports the concept that the resources required for regeneration can be drawn from the tissue 
found in the vicinity of the lesion, and that if the ratio of damaged to undamaged polyps within a certain area of the colony is low enough to support regeneration, lesions may recover independently of colony size (Meesters et al. 1994).

The colonization of skeletal lesions can be rapid, and a dense community of filamentous algae can develop within 2 to 3 wk. Bak \& Van Es (1980) and Van Woesik (1998) observed that the regeneration of coral lesions can proceed even in the presence of colonizing organisms. In fact, Rogers et al. (1982) showed that the recovering coral tissue can grow right over the algal community. In the algal removal experiment, control lesions grew faster and recovered a higher percentage of their initial lesion area than lesions that were scraped free of colonizers, confirming that lesion regeneration can take place normally even in the presence of colonizers. Although extreme care was exercised to avoid damaging coral polyps along the periphery of the lesions, the slower regeneration of brushed lesions may be attributed to the stress created by the removal of colonizers.

The recovery of Acropora palmata lesions caused by fragmentation provided a test for several hypotheses proposed by previous studies based on the regeneration of experimental lesions. Results presented here show that, as was the case for the recovery of small $\left(1-5 \mathrm{~cm}^{2}\right)$ circular lesions on several coral species, recovery can be affected by lesion size, shape, and the extent of the initial damage. Similarly, the recovery of A. palmata lesions of a wide size range $\left(1-20 \mathrm{~cm}^{2}\right)$ was found to be dependent on a limited amount of energy that results in an initial burst of regeneration, followed by an exponential response in recovery rates with time.

Acknowledgements. This research was funded by NSF grant no. OCE-9-00649 to the University of Miami, the E. O. Dunn Foundation, Key Biscayne Rotary Club, Sanibel Captiva Shell Club, Bader Fund, and Reitmeister Fellowship. Biscayne National Park (BNP) provided boat and dive support. I thank Richard Curry, Science Director for BNP, as well as C. Rivero and J. Paddon for their help. This manuscript benefited from comments by M. Harwell, P. Fong, N. Ehrhardt, P. W. Glynn, R. Curry, J. Bohnsack, W. P. Cropper Jr, and 3 anonymous reviewers.

\section{LITERATURE CITED}

Bak RPM (1983) Neoplasia, regeneration and growth in the reef-building coral Acropora palmata. Mar Biol 77 221-227

Bak RPM, Criens SR (1981) Survival after fragmentation of colonies of Madracis mirabilis, Acropora palmata, and A cervicornis (Scleractinia) and the subsequent impact of a coral disease. Proc 4th Int Coral Reef Symp, Manila 2: 221-227

Bak RPM, Van Es YS (1980) Regeneration of superficial dam- age in the scleractinian corals Agaricia agaricites f. purpurea and Porites astreoides. Bull Mar Sci 30:883-887

Bak RPM, Brouns JJWM, Heys FML (1977) Regeneration and aspects of spatial competition in the scleractinian corals Agaricia agaricites and Montastrea annularis. Proc 3rd Int Coral Reef Symp, Miami 2:143-148

Bythell J, Sheppard C (1993) Mass mortality of Caribbean shallow corals. Mar Pollut Bull 26:296-297

Chadwick NE, Loya Y (1990) Regeneration after experimental breakage in the solitary reef coral Fungia granulosa Klunzinger, 1879. J Exp Mar Biol Ecol 142:221-234

Chamberlain JA Jr (1978) Mechanical properties of coral skeleton: compressive strength and its adaptive significance. Paleobiology 4:419-435

Connell JH (1973) Population ecology of reef-building corals. In: Jones OA, Endean R (eds) Biology and geology of coral reefs, Vol 2. Academic Press, New York, p 205-245

Gladfelter EH, Monahan RK, Gladfelter WB (1978) Growth rates of five reef-building corals in the northeastern Caribbean. Bull Mar Sci 28:728-734

Gladfelter WB (1991) Population structure of Acropora palmata on the windward forereef, Buck Island National Monument: seasonal and catastrophic changes 1988-1989. In: Gladfelter EH, Bythell JC, Gladfelter WB (eds) Ecological studies of Buck Island Reef National Monument, St. Croix, US Virgin Islands. A quantitative assessment of selected components of the coral reef ecosystem and establishment of long term monitoring sites, Part I, Chap 5. US Department of the Interior, National Park Service, US Virgin Islands, $\mathrm{p}$ 1-21

Gladfelter WB, Gladfelter EH, Monahan RK, Ogden JC, Dill RF (1977) Environmental studies of Buck Island Reef National Monument, St. Croix, US Virgin Islands. US Department of the Interior, National Park Service, US Virgin Islands

Glynn PW (1973) Aspects of the ecology of coral reefs in the western Atlantic region. In: Jones OA, Endean R (eds) Biology and geology of coral reefs, Vol 2. Academic Press, New York, p 271-325

Graus RR, Chamberlain JA, Boker AM (1977) Structural modification of corals in relation to waves and currents. In:

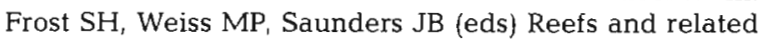
carbonates-ecology and sedimentology. Studies in Geology, no. 4. Am Assoc Petr Geol Mem Ann Arbor, MI, p 135-153

Guzmán HM, Burns KA, Jackson JBC (1994) Injury, regeneration and growth of Caribbean reef corals after a major oil spill in Panama. Mar Ecol Prog Ser 105:231-241

Hawkins JP, Roberts CM (1992) Effects of recreational SCUBA diving on fore-reef slope communities of coral reefs. Biol Conserv 62:171-178

Hernandez-Ávila ML, Roberts HH, Rouse LJ (1977) Hurricane-generated waves and coastal boulder rampart formation. Proc 3rd Int Coral Reef Symp, Miami 1:71-78

Highsmith RC (1982) Reproduction by fragmentation in corals. Mar Ecol Prog Ser 7:207-226

Hutchings PA (1986) Biological destruction of coral reefs. Coral Reefs 4:239-252

Knowlton N, Lang JC, Rooney MC, Clifford P (1981) Evidence for delayed mortality in hurricane-damaged Jamaican staghorn corals. Nature 294:251-252

Knowlton N, Lang JC, Keller BD (1988) Fate of staghorn coral isolates on hurricane-damaged reefs in Jamaica: the role of predators. Proc 6th Int Coral Reef Symp Australia 2:83-88

Kobayashi A (1984) Regeneration and regrowth of fragmented colonies of the hermatypic corals Acropora formosa and Acropora nasuta. Galaxea 3:13-23 
Liddle MJ, Kay AM (1987) Resistance, survival and recovery of trampled corals on the Great Barrier Reef. Biol Conserv $42: 1-18$

Lirman D (1997) Disturbance ecology of the Caribbean coral Acropora palmata. PhD dissertation, University of Miami

Lirman D, Fong P (1995) The effects of Hurricane Andrew and Tropical Storm Gordon on Florida reefs. Coral Reefs 14: 172

Lirman D, Fong P (1996) Susceptibility of coral communities to storm intensity, duration, and frequency. Proc 8th Int Coral Reef Symp, Panama 1:561-566

Lirman D, Fong P (1997) Patterns of damage to the branching coral Acropora palmata following Hurricane Andrew: damage and survivorship of hurricane-generated asexual recruits. J Coastal Res 13:67-72

Loya Y (1976) Skeletal regeneration in a Red Sea scleractinian coral population. Nature 261:490-491

Meesters EH, Bak RPM (1995) Age-related deterioration of a physiological function in the branching coral Acropora palmata. Mar Ecol Prog Ser 121:203-209

Meesters EH, Bos A, Gast GJ (1992) Effects of sedimentation and lesion position on coral tissue regeneration. Proc 7 th Int Coral Reef Symp, Guam 2:681-688

Meesters EH, Noordeloos M, Bak RPM (1994) Damage and regeneration: links to growth in the reef-building coral Montastrea annularis. Mar Ecol Prog Ser 112:119-128

Meesters EH, Wesseling I, Bak RPM (1996) Partial mortality in three species of reef-building corals (Scleractinia) and the relation with colony morphology. Bull Mar Sci 58:838-852

Meesters EH, Pauchli W, Bak RPM (1997) Predicting regeneration of physical damage on a reef-building coral by regeneration capacity and lesion shape. Mar Ecol Prog Ser 146:91-99

Mitchell-Tapping HJ (1983) Experimental fracturing of vari-

Editorial responsibility: Rolf Bak (Contributing Editor),

Den Burg, The Netherlands ous corals in the reef environment. Caribb J Sci 19:49-51

Oren U, Benayahu Y, Loya Y (1997) Effect of lesion size and shape on regeneration of the Red Sea coral Favia favus. Mar Ecol Prog Ser 146:101-107

Pearse VB, Muscatine L (1971) Role of symbiotic algae (zooxanthellae) in coral calcification. Biol Bull 141:350-363

Rappaport EN, Avila LA (1995) 1994 Atlantic hurricane season summary. In: Tait LS (ed) Hurricanes: different faces in different places. Proc 17 th Annual National Hurricane Conference, Atlantic City, p 1-8

Rogers CS, Suchanek, TH, Pecorá FA (1982) Effects of hurricanes David and Frederic (1979) on shallow Acropora palmata reef communities: St. Croix, U.S. Virgin Islands. Bull Mar Sci 32:532-548

Schuhmacher H, Plewka M (1981) The adaptive significance of mechanical properties versus morphological adjustments in skeletons of Acropora palmata and Acropora cervicornis (Cnidaria, Scleractinia). Proc 4th Int Coral Reef Symp, Manila 2:121-128

Sokal RR, Rohlf FJ (1981) Biometry, 2nd edn. WH Freeman \& $\mathrm{Co}$, New York

Storm Data (1994) National Climatic Data Center. NOAA. Asheville, NC

Van Veghel MLJ, Bak RPM (1994) Reproductive characteristics of the polymorphic Caribbean reef building coral Montastrea annularis. III. Reproduction in damaged and regenerating colonies. Mar Ecol Prog Ser 109:229-233

Van Woesik R (1998) Lesion healing on massive Porites spp corals. Mar Ecol Prog Ser 164:213-220

Wable CM (1983) Regeneration of injuries among Jamaican gorgonians: the roles of colony physiology and environment. Biol Bull 165:778-790

Wells SM (ed) (1988) Coral reefs of the world, Vol 1 UNEP/IUCN, Columbia University Press, New York

Submitted: August 25, 1999; Accepted: November 10, 1999

Proofs received from author(s): March 28, 2000 